medRxiv preprint doi: https://doi.org/10.1101/2021.05.28.21257993; this version posted May 31, 2021. The copyright holder for this preprint (which was not certified by peer review) is the author/funder, who has granted medRxiv a license to display the preprint in perpetuity. It is made available under a CC-BY-NC-ND 4.0 International license .

\title{
The UGT2A1/UGT2A2 locus is associated with COVID-19-related anosmia
}

Authors: Janie F. Shelton ${ }^{1}$, Anjali J. Shastri ${ }^{1}$, The 23 andMe COVID-19 Team ${ }^{1}$, Stella Aslibekyan ${ }^{1}$, and Adam Auton ${ }^{1}$

1. 23andMe Inc., 223 N Mathilda Ave, Sunnyvale, CA 94086

\section{Abstract}

Loss of sense of smell is a characteristic symptom of infection with SARS-CoV-2. However, specific mechanisms linking infection with loss of smell are poorly understood. Using self-reported symptom data from the 23andMe COVID-19 study, we describe the demographic patterns associated with COVID-19 related anosmia, and find the symptom is more often reported in women and younger respondents, and less often by those of East Asian and African American ancestry compared to those of European ancestry. We ran a trans-ethnic genome-wide association study (GWAS) comparing loss of smell or taste $(n=47,298)$ with no loss of smell or taste $(n=22,543)$ among those with a positive SARS-CoV-2 test result. We identified an association (rs7688383) in the vicinity of the UGT2A1 and UGT2A2 genes (OR=1.115, $\mathrm{p}$-value $\left.=4 \times 10^{-15}\right)$, which have been linked to olfactory function. These results may shed light on the biological mechanisms underlying COVID-19 related anosmia.

\section{Introduction}

Loss of sense of smell, or anosmia, is the main neurological symptom and one of the earliest and most commonly reported indicators of the acute phase of SARS-CoV-2 infection. While a large fraction of COVID-19 patients report loss of smell or taste, the underlying mechanism remains unclear. ${ }^{1}$

23andMe is a direct-to-consumer genetic testing company with over 10 million genotyped customers. As part of the 23andMe service, customers are genotyped on SNP microarrays and offered the opportunity to participate in scientific research, and approximately $80 \%$ of customers consent to do so. In general, research participation is conducted via online surveys, which research participants can complete at any time. Research participants are re-contactable and can be invited to participate in new surveys that are developed over time.

Here, we conducted a genome-wide association study (GWAS) of COVID-19-related anosmia, having collected data from over one million research participants as previously described. ${ }^{2}$ By asking 23andMe research participants to report the symptoms they encountered during their COVID-19 experience, we identified 47,298 individuals who reported loss of taste or smell along with a SARS-CoV-2 positive test, and 22,543 individuals that reported a positive test but did not experience loss of taste or smell. We performed GWAS separately in samples of European, Latino, African American, East Asian, and South Asian ancestries and used the resulting data to perform a trans-ethnic meta-analysis.

We identified a strong association at a locus containing the UGT2A1 and UGT2A2 genes. These genes, part of a family of uridine diphosphate glycosyltransferases, are expressed in the olfactory epithelium and function as odorant metabolizing enzymes, facilitating the elimination of exogenous and endogenous compounds and playing a critical role in the physiology of olfaction. ${ }^{3}$ Recent evidence suggests that SARS-CoV-2 impedes olfactory sensation by infecting and compromising the essential functions of olfactory support cells, ${ }^{4}$ which may be modulated by UGT2A1/UGT2A2. Our findings represent the first genetic link to the underlying mechanisms of COVID-19-related anosmia. 
medRxiv preprint doi: https://doi.org/10.1101/2021.05.28.21257993; this version posted May 31, 2021. The copyright holder for this preprint (which was not certified by peer review) is the author/funder, who has granted medRxiv a license to display the preprint in perpetuity. It is made available under a CC-BY-NC-ND 4.0 International license .

\section{Methods}

\section{Overview of study recruitment and data collection}

Participants in this study were recruited from the customer base of 23andMe, Inc., a personal genetics company. Participants provided informed consent and participated in the research online, under a protocol approved by the external AAHRPP-accredited IRB, Ethical \& Independent Review Services (E\&I Review). Participants were included in the analysis on the basis of consent status as checked at the time data analyses were initiated.

Full details of the data collection paradigm for this study have been described previously. ${ }^{2}$ In brief, primary recruitment was carried out by email to approximately 6.7 million 23andMe research participants over 18 years of age and living in the United States or the United Kingdom. Additionally, pre-existing customers were invited to participate in the study through promotional materials on the 23andMe website, the 23andMe mobile application, and via social media. Study participation consisted solely of web-based surveys, including an initial baseline survey, and three follow-up surveys fielded 1-month following completion of the baseline survey. Enrollment continued after the initial recruitment efforts until a data-freeze was taken for this study in March 2021, when 1.3 million participants had completed the baseline survey.

\section{Phenotype definitions for GWAS}

Using the information derived from the surveys, we defined a single phenotype to contrast COVID-19-positive individuals that experienced COVID-19-related anosmia from those that did not. Specifically, participants were asked to respond to the question; "Have you been tested for COVID-19 (coronavirus)?", with possible responses; "Yes, it was positive / Yes, it was negative / No / My results are pending / I'm not sure". Of those that responded "Yes, it was positive", we further considered the question; "During your illness, did you experience any of the following symptoms?" to which participants could select as many as needed from the following list of responses, "Muscle or body aches / Fatigue / Dry cough / Sore throat / Coughing up of sputum or phlegm (productive cough) / Loss of smell or taste / Chills / Difficulty breathing or shortness of breath / Pressure or tightness in upper chest / Diarrhea / Nausea or vomiting / Sneezing / Loss of appetite / Runny nose / Headache / Intensely red or watery eyes". We defined cases as SARS-CoV-2 test positive individuals that also reported "Loss of smell or taste", and controls as SARS-CoV-2 test positive individuals who did not report "Loss of smell or taste". While some participants reported a COVID-19 diagnosis absent a confirmed positive test for SARS-CoV-2, we did not include such individuals within this analysis.

\section{Descriptive statistics}

Sample sizes and proportions were calculated by age, sex, and ancestry. Differences in anosmia by sex were statistically evaluated with a chi-square statistics, and mean difference in age were evaluated with a t-test. A logistic regression model was constructed to evaluate anosmia as a function of ancestry, age (categorical), and sex. All analyses were conducted in $\mathrm{R}$ statistical software version 3.6.3.

\section{Genotyping and SNP imputation}

DNA extraction and genotyping were performed on saliva samples by CLIA-certified and CAP-accredited clinical laboratories of Laboratory Corporation of America. Samples were genotyped on one of five genotyping platforms. The V1 and V2 platforms were variants of the Illumina HumanHap550 + BeadChip and contained a total of about 560,000 SNPs, including about 25,000 custom SNPs selected by 23andMe. The V3 platform was 
medRxiv preprint doi: https://doi.org/10.1101/2021.05.28.21257993; this version posted May 31, 2021. The copyright holder for this preprint (which was not certified by peer review) is the author/funder, who has granted medRxiv a license to display the preprint in perpetuity. It is made available under a CC-BY-NC-ND 4.0 International license .

based on the Illumina OmniExpress + BeadChip and contained a total of about 950,000 SNPs and custom content to improve the overlap with our V2 array. The V4 platform was a fully custom array of about 950,000 SNPs and included a lower redundancy subset of V2 and V3 SNPs with additional coverage of lower-frequency coding variation. The V5 platform was based on the Illumina GSA array, consisting of approximately 654,000 pre-selected SNPs and approximately 50,000 custom content variants. Samples that failed to reach $98.5 \%$ call rate were re-analyzed. Individuals whose analyses failed repeatedly were re-contacted by 23 andMe customer service to provide additional samples, as is done for all 23andMe customers.

Participant genotype data were imputed using the Haplotype Reference Consortium (HRC) panel ${ }^{5}$, augmented by the Phase 31000 Genomes Project panel ${ }^{6}$ for variants not present in HRC. We phased and imputed data for each genotyping platform separately. For the non-pseudoautosomal region of the $\mathrm{X}$ chromosome, males and females were phased together in segments, treating the males as already phased; the pseudoautosomal regions were phased separately. We then imputed males and females together, treating males as homozygous pseudo-diploids for the non-pseudoautosomal region.

\section{Genome-wide association study (GWAS)}

Genotyped participants were included in GWAS analyses on the basis of ancestry as determined by a genetic ancestry classification algorithm. ${ }^{7}$ For each phenotype, we selected a set of unrelated individuals so that no two individuals shared more than 700cM of DNA identical by descent (IBD). For case-control phenotypes, if a case and a control were identified as having at least $700 \mathrm{cM}$ of DNA IBD, we preferentially discarded the control from the sample.

For case-control comparisons, we tested for association using logistic regression, assuming additive allelic effects. For tests using imputed data, we use the imputed dosages rather than best-guess genotypes. We included covariates for age, age squared, sex, a sex:age interaction, the top ten principal components to account for residual population structure, and dummy variables to account for genotyping platform. The association test $p$-value was computed using a likelihood ratio test, which in our experience is better behaved than a Wald test on the regression coefficient. Results for the X chromosome were computed similarly, with men coded as if they were homozygous diploid for the observed allele.

We ran GWAS for each phenotype separately, and combined both genotyped and imputed data. When choosing between imputed and genotyped GWAS results, we favored the imputed result, unless the imputed variant was unavailable or failed quality control (QC). For imputed variants, we removed variants with low imputation quality $\left(r^{2}<0.5\right.$ averaged across batches, or a minimum $\left.r^{2}<0.3\right)$ or with evidence of batch effects (ANOVA F-test across batches, $p$-value $<10^{-50}$ ). For genotyped variants, we removed variants only present on our V1 or V2 arrays (due to small sample size) that failed a Mendelian transmission test in trios ( $p$-value $<$ $10^{-20}$ ), that failed a Hardy-Weinberg test in Europeans $\left(p-\right.$ value $<10^{-20}$ ), failed a batch effect test (ANOVA p-value $<10^{-50}$ ), or had a call rate $<90 \%$.

We repeated the GWAS analysis separately in each population cohort for which we had sufficient data (European, Latino, African American, East Asian, and South Asian), and the resulting summary statistics were corrected for inflation using genomic control when the inflation factor was estimated to be greater than 1 . We then performed trans-ethnic meta-analysis using a fixed effects model (inverse variance method ${ }^{8}$ ), restricting to variants of at least $1 \%$ minor allele frequency in the pooled sample, and minor allele count $>30$ within each subpopulation. Both the input GWAS and resulting meta-analysis were corrected for inflation using genomic control where necessary. 
medRxiv preprint doi: https://doi.org/10.1101/2021.05.28.21257993; this version posted May 31, 2021. The copyright holder for this preprint (which was not certified by peer review) is the author/funder, who has granted medRxiv a license to display the preprint in perpetuity. It is made available under a CC-BY-NC-ND 4.0 International license .

Within each GWAS, we identified regions with genome-wide significant (GWS) associations. We define the region boundaries by identifying all SNPs with $\mathrm{p}$-value $<10^{-5}$ within the vicinity of a GWS association, and then grouping these regions into intervals so that no two regions are separated by less than $250 \mathrm{~kb}$. We consider the SNP with the smallest p-value within each interval to be the index SNP. Within each region, we calculated a credible set using the method of Maller et al. ${ }^{9}$

\section{Results}

\section{Respondent characteristics}

We previously reported the use of the 23andMe research platform to collect data regarding participants' experiences with COVID-19 during the pandemic. ${ }^{2}$ From this data, $68 \%$ of COVID-19 cases reported loss of smell or taste $(47,298$ with anosmia out of a total of 69,841 of respondents with a positive SARS-CoV-2 test). Female respondents were more likely than males (72\% vs. $61 \%)$ to report anosmia (chi-square test, $p$-value < $2.2 \times 10-16$ ), as were younger individuals (mean age of those with loss of smell $=41$ years vs. those without $=$ 45 years, $p$-value $<2.2 \times 10-16$, Welch's t-test). Among genetically determined ancestral groups, rates of anosmia varied between $63 \%-70 \%$ (Table 1). As expected, compared to other symptoms surveyed, anosmia was much more common among those with a SARS-CoV-2 positive test compared to those with other cold or flu-like symptoms who tested negative for SARS-CoV-2 (Supplementary Figure 1). In a logistic regression model predicting loss of smell by ancestry, adjusted for age and sex, individuals of East Asian or African American ancestry were less likely to report loss of smell and taste ( $O R=0.8$ and 0.88 respectively) relative to Europeans (Table 2).

\section{GWAS}

We conducted GWAS within each population separately before performing a trans-ethnic meta-analysis using a fixed-effects model. Each input GWAS was corrected for inflation via genomic control (lambda = 1.029, 1.037, 1.024, 1.042, and 1.071 within the European, Latino, African American, East Asian, and South Asian GWAS respectively), as was the subsequent meta-analysis (lambda $=1.001$ ).

Within the trans-ethnic meta-analysis, we identified a single associated loci in the vicinity of the UGT2A1 and UGT2A2 genes on chromosome 4 (chr4q13.3) (Figures 1 and 2). No other locus achieved genome-wide significance in the trans-ethnic meta-analysis or in any of the input populations (Supplementary Figures 2-6). The index SNP at this locus was rs7688383 (C/T, with T being the risk allele. $p$-value $=1.4 \mathrm{e}-14, \mathrm{OR}=1.11)$. This SNP has frequency between $19 \%$ and $37 \%$, depending on population (Table 3 ). While the majority of support within the trans-ethnic analysis comes from the European population (for which we have the largest sample size; Supplementary Figures 7-11), effect sizes are consistent across populations (Figure 3).

\section{Discussion}

Loss of smell or taste is a notable symptom of COVID-19. It is distinct from other viral symptoms in its sudden onset $^{10}$, and can occur in the absence of other indications of illness. Here, we report $68 \%$ of those with a SARS-CoV-2 test experienced anosmia, which is higher than many other published estimates. ${ }^{11}$ This may be due to the relatively large fraction of milder cases in our study sample compared to clinically ascertained samples, as less severe cases of COVID-19 have been found to more often report anosmia than critical cases. ${ }^{12}$ Further, because the prevalence of this symptom was found to decline with age and is more often 
medRxiv preprint doi: https://doi.org/10.1101/2021.05.28.21257993; this version posted May 31, 2021. The copyright holder for this preprint (which was not certified by peer review) is the author/funder, who has granted medRxiv a license to display the preprint in perpetuity. It is made available under a CC-BY-NC-ND 4.0 International license.

reported by females than males, our study sample would be expected to have higher rates of anosmia compared to a case population followed-up after hospitalization.

While many mechanistic explanations have been proposed ${ }^{4}$ for the COVID-19-related loss of smell, experimental studies suggest that the loss of smell is related to damage to the cilia and olfactory epithelium, but not infection of the olfactory neurons. For example, in an experiment where hamsters were nasally infected with SARS-CoV-2, the olfactory epithelium and cilia became very damaged, which can completely inhibit the ability to smell, but no infection was observed in the olfactory neurons. ${ }^{13}$ Recent evidence suggests that SARS-CoV-2 enters and accumulates in olfactory support cells, specifically, sustentacular cells, which abundantly express the viral entry proteins ACE2 and TMPRSS2 unlike olfactory neurons. ${ }^{14,15}$ These support cells are metabolically and functionally associated with olfactory neurons and with odorant signal transduction (processing odorants by endocytosing the odorant-binding protein complex, detoxifying, maintaining the cilia of mature olfactory receptor neurons, and maintaining epithelial integrity). It has been proposed that olfactory sensation is impaired when these essential functions are disrupted, causing cilial impairment. ${ }^{4}$

We have identified a genetic locus containing two genes (UGT2A1 and UGT2A2) expected to have a relationship with olfactory function. Given their localization and essential function in the metabolization and detoxification of such compounds, these genes may play a role in the physiology of infected cells and the resulting functional impairment that contributes to loss of ability to smell. We hope that the identification of this genetic association with COVID-19 related anosmia may serve as a clue as to how the virus affects cells in the nasal pathway. 
medRxiv preprint doi: https://doi.org/10.1101/2021.05.28.21257993; this version posted May 31, 2021. The copyright holder for this preprint (which was not certified by peer review) is the author/funder, who has granted medRxiv a license to display the preprint in perpetuity.

\section{References}

1. Mutiawati, E. et al. Anosmia and dysgeusia in SARS-CoV-2 infection: incidence and effects on COVID-19 severity and mortality, and the possible pathobiology mechanisms - a systematic review and meta-analysis. F1000Research 10, (2021).

2. Shelton, J. F. et al. Trans-ethnic analysis reveals genetic and non-genetic associations with COVID-19 susceptibility and severity. medRxiv 2020.09.04.20188318 (2020) doi:10.1101/2020.09.04.20188318.

3. Neiers, F., Jarriault, D., Menetrier, F., Briand, L. \& Heydel, J.-M. The odorant metabolizing enzyme UGT2A1: Immunolocalization and impact of the modulation of its activity on the olfactory response. PLOS ONE 16, e0249029 (2021).

4. Butowt, R. \& von Bartheld, C. S. Anosmia in COVID-19: Underlying Mechanisms and Assessment of an Olfactory Route to Brain Infection. The Neuroscientist 1073858420956905 (2020) doi:10.1177/1073858420956905.

5. McCarthy, S. et al. A reference panel of 64,976 haplotypes for genotype imputation. Nat. Genet. 48, 1279-1283 (2016).

6. Auton, A. et al. A global reference for human genetic variation. Nature 526, 68-74 (2015).

7. Durand, E. Y., Do, C. B., Mountain, J. L. \& Macpherson, J. M. Ancestry Composition: A Novel, Efficient Pipeline for Ancestry Deconvolution. http://biorxiv.org/lookup/doi/10.1101/010512 (2014) doi:10.1101/010512.

8. Willer, C. J., Li, Y. \& Abecasis, G. R. METAL: fast and efficient meta-analysis of genomewide association scans. Bioinformatics 26, 2190-2191 (2010).

9. Maller, J. B. et al. Bayesian refinement of association signals for 14 loci in 3 common diseases. Nat. Genet. 44, 1294-1301 (2012).

10. Kang, Y. J., Cho, J. H., Lee, M. H., Kim, Y. J. \& Park, C.-S. The diagnostic value of detecting sudden smell loss among asymptomatic COVID-19 patients in early stage: The possible early sign of COVID-19. Auris. Nasus. Larynx 47, 565-573 (2020).

11. Agyeman, A. A., Chin, K. L., Landersdorfer, C. B., Liew, D. \& Ofori-Asenso, R. Smell and Taste 
medRxiv preprint doi: https://doi.org/10.1101/2021.05.28.21257993; this version posted May 31, 2021. The copyright holder for this preprint

(which was not certified by peer review) is the author/funder, who has granted medRxiv a license to display the preprint in perpetuity.

It is made available under a CC-BY-NC-ND 4.0 International license .

Dysfunction in Patients With COVID-19: A Systematic Review and Meta-analysis. Mayo Clin. Proc. 95, $1621-1631$ (2020).

12. Lechien, J. R. et al. Prevalence and 6-month recovery of olfactory dysfunction: a multicentre study of 1363 COVID-19 patients. J. Intern. Med. n/a,.

13. Bryche, B. et al. Massive transient damage of the olfactory epithelium associated with infection of sustentacular cells by SARS-CoV-2 in golden Syrian hamsters. Brain. Behav. Immun. 89, 579-586 (2020).

14. Brann, D. H. et al. Non-neuronal expression of SARS-CoV-2 entry genes in the olfactory system suggests mechanisms underlying COVID-19-associated anosmia. Sci. Adv. 6, eabc5801 (2020).

15. Expression of the SARS-CoV-2 Entry Proteins, ACE2 and TMPRSS2, in Cells of the Olfactory Epithelium: Identification of Cell Types and Trends with Age | ACS Chemical Neuroscience.

https://pubs.acs.org/doi/10.1021/acschemneuro.0c00210.

\section{Acknowledgements}

We thank the 23andMe research participants and employees who made this study possible. The 23andMe Research Team is:

Aaron A. Petrakovitz, Aaron Kleinman, Adam Auton, Alejandro Hernandez, Anjali J. Shastri, Barry Hicks, Briana Cameron, Catherine H. Weldon, Christophe Toukam Tchakouté, Corinna Wong, Daniella Coker, David A. Hinds, Devika Dhamija, Elizabeth Babalola, Elizabeth S. Noblin, Emily Bullis, Ethan M. Jewett, G. David Poznik, Gabriel Cuellar Partida, Janie F. Shelton, Jared O'Connell, Jessica Bielenberg, Jey McCreight, Jingchunzi Shi, Joanna L. Mountain, Joyce Y. Tung, Karl Heilbron, Katarzyna Bryc, Katelyn Kukar, Keng-Han Lin, Kipper Fletez-Brant, Matthew H. Mclntyre, Maya Lowe, Meghan E. Moreno, Morgan Schumacher, Peter Wilton, Pierre Fontanillas, Pooja M. Gandhi, Priyanka Nandakumar, Robert K. Bell, Sarah L. Elson, Sayantan Das, Stella Aslibekyan, Steven J. Micheletti, Suyash Shringarpure, Teresa Filshtein, Vinh Tran, Wei Wang, Will Freyman, Xin Wang, Yunxuan Jiang

\section{3andMe COVID-19 Team}

Members of the 23andMe COVID-19 Team are: Adam Auton, Adrian Chubb, Alison Fitch, Alison Kung, Amanda Altman, Andy Kill, Anjali Shastri, Antony Symons, Catherine Weldon, Chelsea Ye, Daniella Coker, Janie F. Shelton, Jason Tan, Jeff Pollard, Jennifer McCreight, Jess Bielenberg, John Matthews, Johnny Lee, Lindsey Tran, Maya Lowe, Michelle Agee, Monica Royce, Nate Tang, Pooja Gandhi, Raffaello d'Amore, Ruth Tennen, Scott Dvorak, Scott Hadly, Stella Aslibekyan, Sungmin Park, Taylor Morrow, Teresa Filshtein Sonmez, Trung Le, and Yiwen Zheng. All team members are employees of 23andMe Inc.

\section{Author Contributions Statement}

JFS, AJS, SA, and AA designed this study. The 23andMe COVID-19 Team developed the recruitment and participant engagement strategy and acquired and processed the data. JFS, SA, and AA analyzed the data. 
medRxiv preprint doi: https://doi.org/10.1101/2021.05.28.21257993; this version posted May 31, 2021. The copyright holder for this preprint (which was not certified by peer review) is the author/funder, who has granted medRxiv a license to display the preprint in perpetuity. It is made available under a CC-BY-NC-ND 4.0 International license.

JFS, AJS, and AA interpreted the data. JFS, AJS, and AA wrote the manuscript. All authors participated in the preparation of the manuscript by reading and commenting on drafts prior to submission.

\section{Competing Interests Statement}

JFS, AJS, SA, and AA are current or former employees of 23andMe, Inc., and hold stock or stock options in 23andMe. 
medRxiv preprint doi: https://doi.org/10.1101/2021.05.28.21257993; this version posted May 31, 2021. The copyright holder for this preprint (which was not certified by peer review) is the author/funder, who has granted medRxiv a license to display the preprint in perpetuity.

It is made available under a CC-BY-NC-ND 4.0 International license .

\section{Tables and Figures}

Table 1: Sample sizes and percentages comparing self-reported anosmia vs. no anosmia among those with a positive SARS-CoV-2 test result.

\begin{tabular}{|c|c|c|c|c|c|c|}
\hline & & \multicolumn{5}{|c|}{ Positive SARS-CoV-2 test result } \\
\hline & & Anosmia & $\%$ & No anosmia & $\%$ & Total \\
\hline & Total & 47,298 & $68 \%$ & 22,543 & $32 \%$ & 69,841 \\
\hline \multirow[t]{2}{*}{ Sex } & Female & 31,608 & $72 \%$ & 12,562 & $28 \%$ & 44,170 \\
\hline & Male & 15,690 & $61 \%$ & 9,981 & $39 \%$ & 25,671 \\
\hline \multirow[t]{7}{*}{ Age } & $<=25$ & 6,276 & $71 \%$ & 2,620 & $29 \%$ & 8,896 \\
\hline & $26-35$ & 13,855 & $73 \%$ & 5,134 & $27 \%$ & 18,989 \\
\hline & $36-45$ & 10,539 & $70 \%$ & 4,552 & $30 \%$ & 15,091 \\
\hline & $46-55$ & 8,321 & $67 \%$ & 4,080 & $33 \%$ & 12,401 \\
\hline & $56-65$ & 5,673 & $62 \%$ & 3,522 & $38 \%$ & 9,195 \\
\hline & $66-75$ & 2,059 & $51 \%$ & 1,945 & $49 \%$ & 4,004 \\
\hline & $>75$ & 574 & $45 \%$ & 689 & $55 \%$ & 1,263 \\
\hline \multirow[t]{6}{*}{ Ancestry } & European & 33,336 & $67 \%$ & 16,257 & $33 \%$ & 49,593 \\
\hline & Latino & 9,233 & $70 \%$ & 3,944 & $30 \%$ & 13,177 \\
\hline & $\begin{array}{l}\text { African American or } \\
\text { black }\end{array}$ & 1,860 & $66 \%$ & 949 & $34 \%$ & 2,809 \\
\hline & East Asian & 626 & $65 \%$ & 338 & $35 \%$ & 964 \\
\hline & South Asian & 284 & $63 \%$ & 167 & $37 \%$ & 451 \\
\hline & Other & 1,959 & $69 \%$ & 888 & $31 \%$ & 2,847 \\
\hline
\end{tabular}


medRxiv preprint doi: https://doi.org/10.1101/2021.05.28.21257993; this version posted May 31, 2021. The copyright holder for this preprint (which was not certified by peer review) is the author/funder, who has granted medRxiv a license to display the preprint in perpetuity.

It is made available under a CC-BY-NC-ND 4.0 International license .

Table 2: Logistic regression model of age, sex, and ancestry, predicting loss of smell or taste among those with a SARS-CoV-2 positive test.

\begin{tabular}{|l|c|c|c|}
\hline & \multicolumn{3}{|c|}{ Model results } \\
\hline & Odds Ratio & $\begin{array}{c}\text { 95\% } \\
\text { confidence } \\
\text { interval }\end{array}$ & p-value \\
\hline European & 1 (REF) & NA & NA \\
\hline Latino & 1.05 & $1.003-1.09$ & 0.033 \\
\hline $\begin{array}{l}\text { African } \\
\text { American or }\end{array}$ & & & \\
\hline Elack & 0.88 & $0.81-0.96$ & 0.003 \\
\hline Soust Asian & 0.80 & $0.70-0.92$ & 0.002 \\
\hline Other & 0.84 & $0.70-1.03$ & 0.09 \\
\hline Female sex & 1.01 & $0.93-1.11$ & 0.79 \\
\hline Age $<25$ & 1.56 & $1.51-1.61$ & $<0.0001$ \\
\hline $26-35$ & 0.99 & $0.94-1.06$ & 0.97 \\
\hline $36-45$ & 1.14 & $1.09-1.20$ & $<0.0001$ \\
\hline $46-55$ & $1.0($ REF) & NA & NA \\
\hline $56-65$ & 0.87 & $0.83-0.92$ & $<0.0001$ \\
\hline $66-75$ & 0.69 & $0.65-0.73$ & $<0.0001$ \\
\hline 75 and older & 0.37 & $0.33-0.42$ & $<0.0001$ \\
\hline
\end{tabular}

Table 3: Genome-wide association statistics (odds ratios and p-values) for rs7688383 for each ethnicity, including allele frequencies and sample sizes for each GWAS and the trans-ethnic meta-analysis summary statistics.

\begin{tabular}{|c|c|c|c|c|c|c|}
\hline Population & $\begin{array}{c}\text { Case / Control } \\
\mathbf{N}\end{array}$ & $\begin{array}{c}\text { Allele } \\
\text { frequency }\end{array}$ & Alleles & $\begin{array}{c}\text { Odds } \\
\text { ratio }\end{array}$ & $\mathbf{9 5 \%} \mathbf{~ I I ~}$ & p-value \\
\hline Europe & $27,786 / 13,903$ & $36.8 \%$ & $\mathrm{C} / \mathrm{T}$ & 1.11 & {$[1.08,1.15]$} & $1.78 \mathrm{E}-11$ \\
\hline South Asian & $230 / 143$ & $32.2 \%$ & $\mathrm{C} / \mathrm{T}$ & 1.26 & {$[0.88,1.82]$} & 0.206 \\
\hline $\begin{array}{c}\text { African } \\
\text { American }\end{array}$ & $1,556 / 804$ & $31.4 \%$ & $\mathrm{C} / \mathrm{T}$ & 1.13 & {$[0.98,1.29]$} & 0.0895 \\
\hline Latino & $7,841 / 3,419$ & $30.1 \%$ & $\mathrm{C} / \mathrm{T}$ & 1.12 & {$[1.05,1.19]$} & 0.0007 \\
\hline East Asian & $557 / 314$ & $19.2 \%$ & $\mathrm{C} / \mathrm{T}$ & 1.18 & {$[0.91,1.53]$} & 0.213 \\
\hline $\begin{array}{c}\text { Meta } \\
\text { analysis }\end{array}$ & $\mathbf{3 7 , 7 9 0 / 1 8 , 5 8 3}$ & & $\mathbf{C} / \mathbf{T}$ & $\mathbf{1 . 1 2}$ & {$[\mathbf{1 . 0 9 , 1 . 1 5 ]}$} & $\mathbf{4 . 1 7 E - 1 5}$ \\
\hline
\end{tabular}


medRxiv preprint doi: https://doi.org/10.1101/2021.05.28.21257993; this version posted May 31, 2021. The copyright holder for this preprint (which was not certified by peer review) is the author/funder, who has granted medRxiv a license to display the preprint in perpetuity.

It is made available under a CC-BY-NC-ND 4.0 International license .

Figure 1: Manhattan plot for the 'Loss of taste or smell' phenotype from the trans-ethnic meta analysis. SNPs achieving genome-wide significance are highlighted in red. The nearest gene to the index SNP is indicated above the relevant association peak.

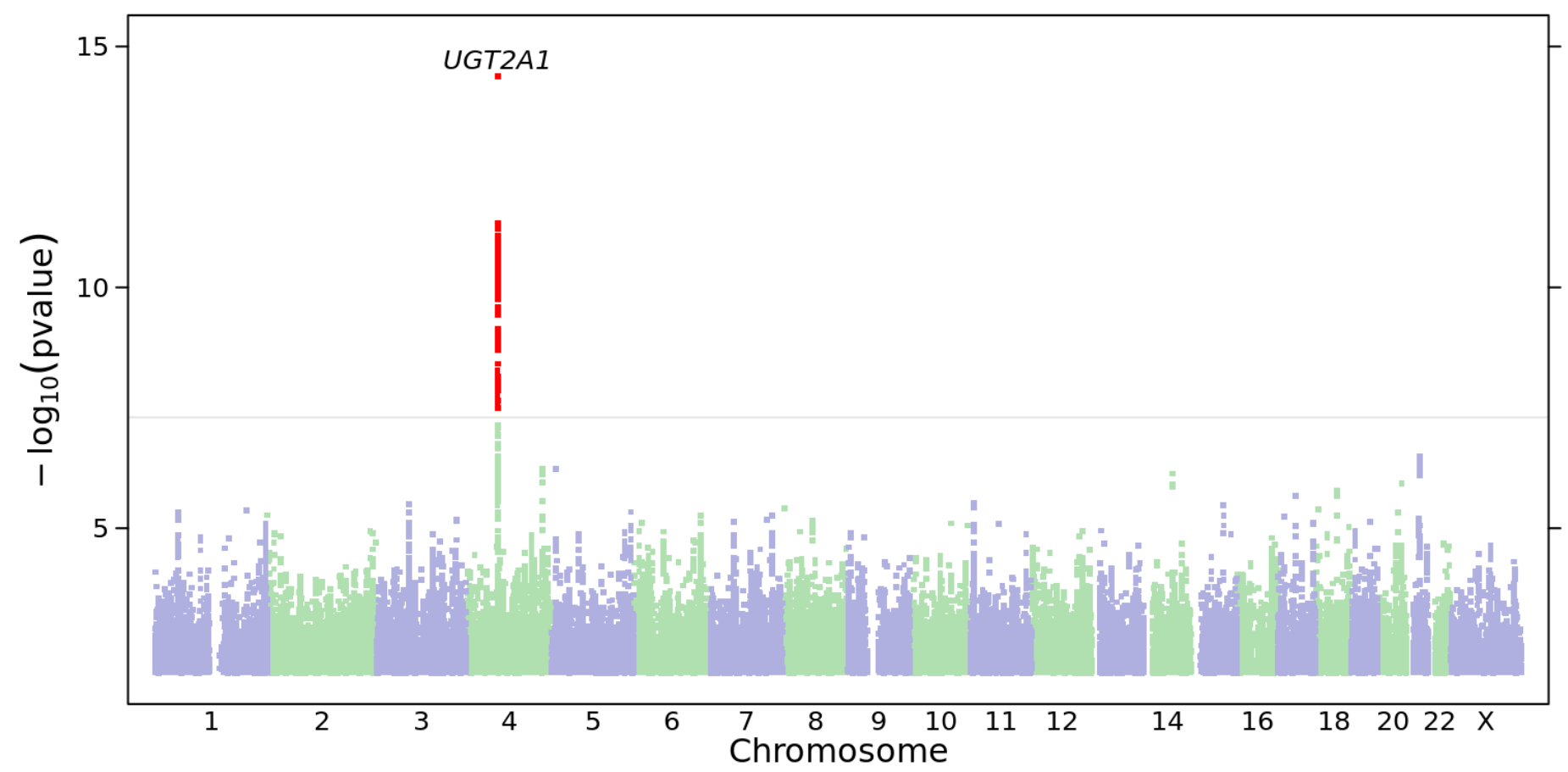

Figure 2: Genetic association with the 'Loss of taste or smell' phenotype: regional plot around the UGT2A1/UGT2A2 locus. Colors indicate strength of linkage disequilibrium relative to the index SNP (rs7688383). Imputed variants are indicated with '+' symbols or ' $x$ ' symbols for coding variants. Where imputed variants weren't available, directly genotyped variants are indicated by 'o' symbols or diamond symbols for coding variants. 
medRxiv preprint doi: https://doi.org/10.1101/2021.05.28.21257993; this version posted May 31, 2021. The copyright holder for this preprint (which was not certified by peer review) is the author/funder, who has granted medRxiv a license to display the preprint in perpetuity.

It is made available under a CC-BY-NC-ND 4.0 International license .

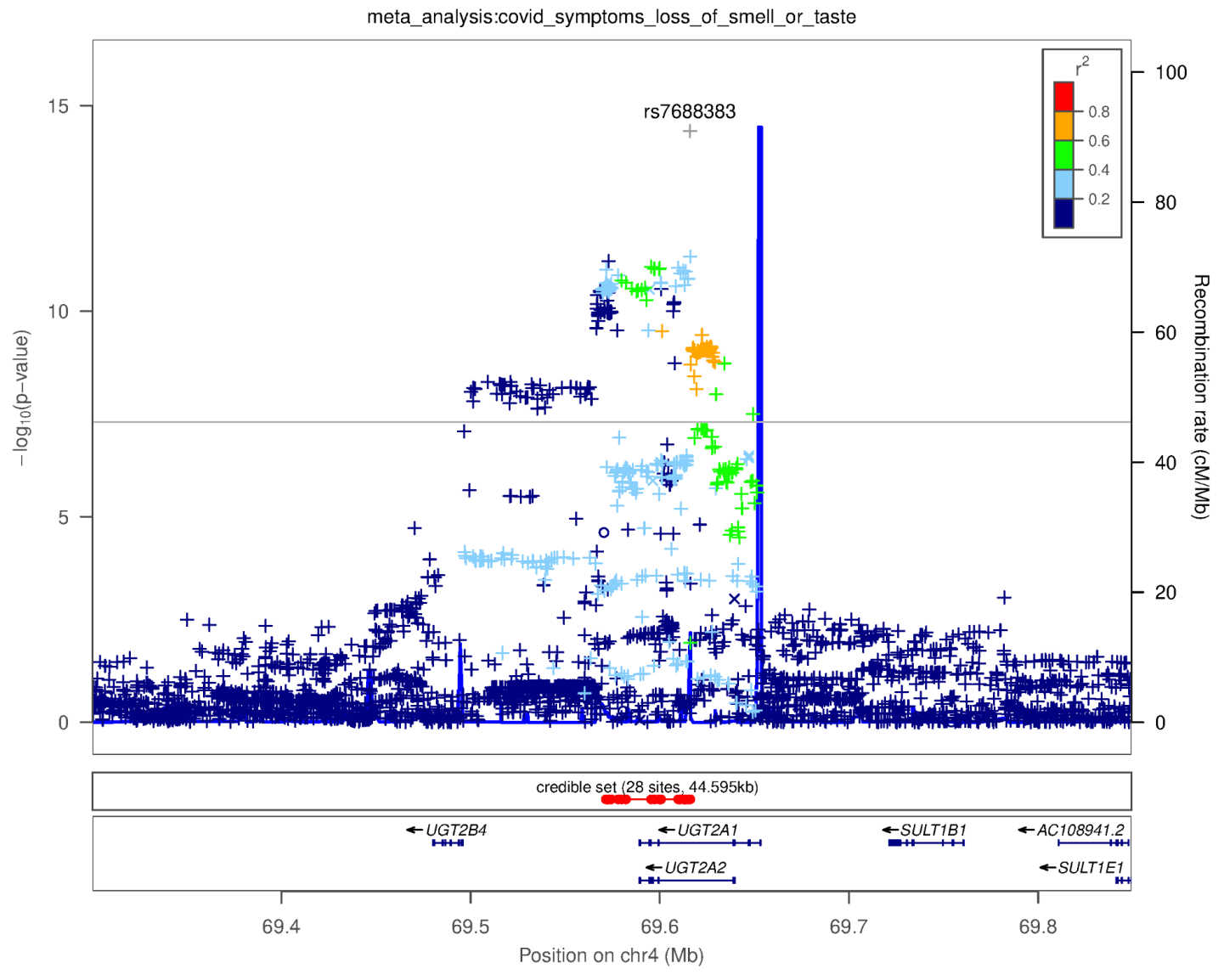


medRxiv preprint doi: https://doi.org/10.1101/2021.05.28.21257993; this version posted May 31, 2021. The copyright holder for this preprint (which was not certified by peer review) is the author/funder, who has granted medRxiv a license to display the preprint in perpetuity.

It is made available under a CC-BY-NC-ND 4.0 International license.

Figure 3: Effect sizes for the index SNP (rs7688383) in each subpopulation and the corresponding meta-analysis.

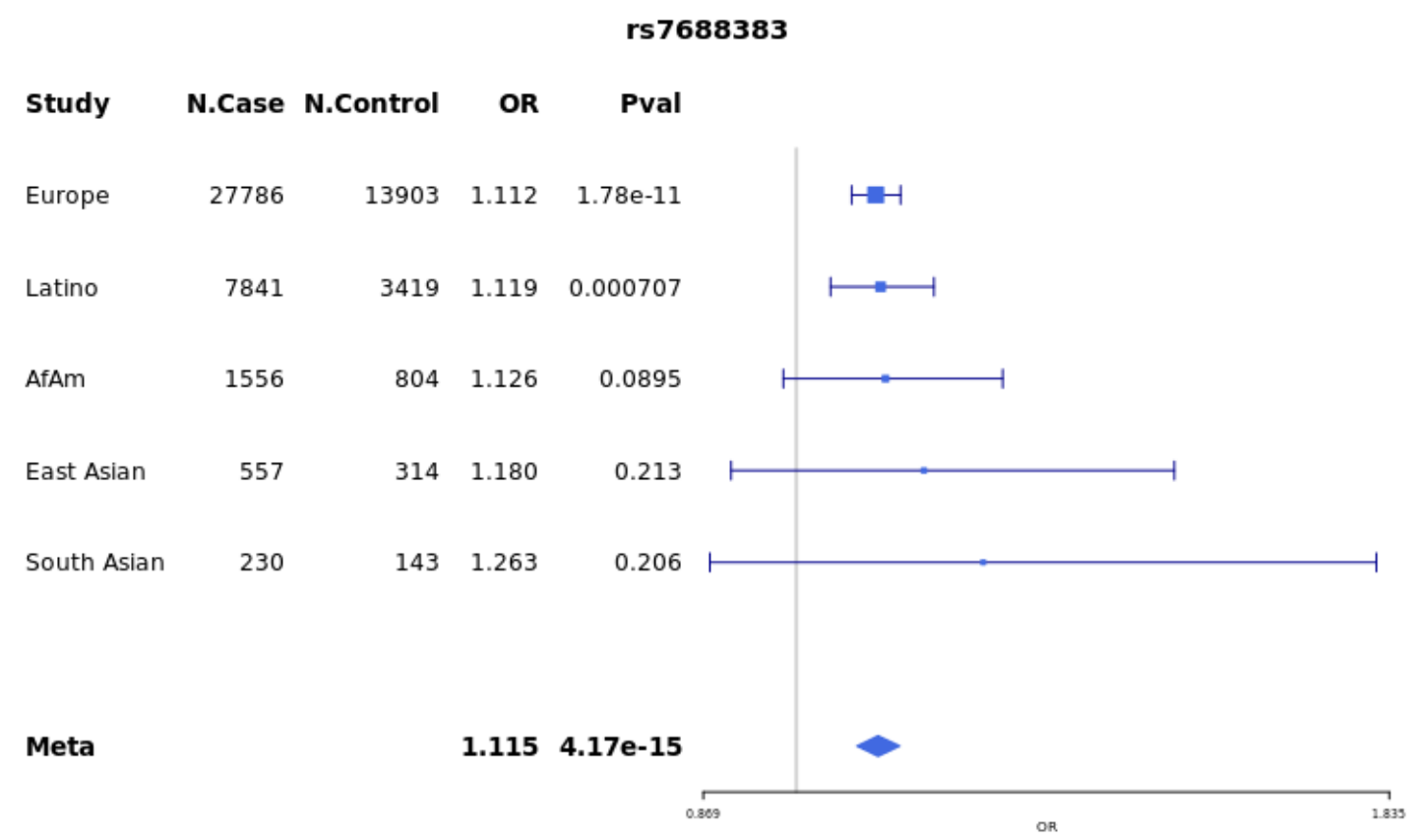


medRxiv preprint doi: https://doi.org/10.1101/2021.05.28.21257993; this version posted May 31, 2021. The copyright holder for this preprint (which was not certified by peer review) is the author/funder, who has granted medRxiv a license to display the preprint in perpetuity.

It is made available under a CC-BY-NC-ND 4.0 International license .

Supplementary Figure 1: Self-reported symptoms experienced during SARS-CoV-2 infection with a positive test as compared to other cold or flu-like illness accompanying a negative SARS-CoV-2 test.

SARS-CoV-2 positive Other cold or flu-like illness

$100 \%$

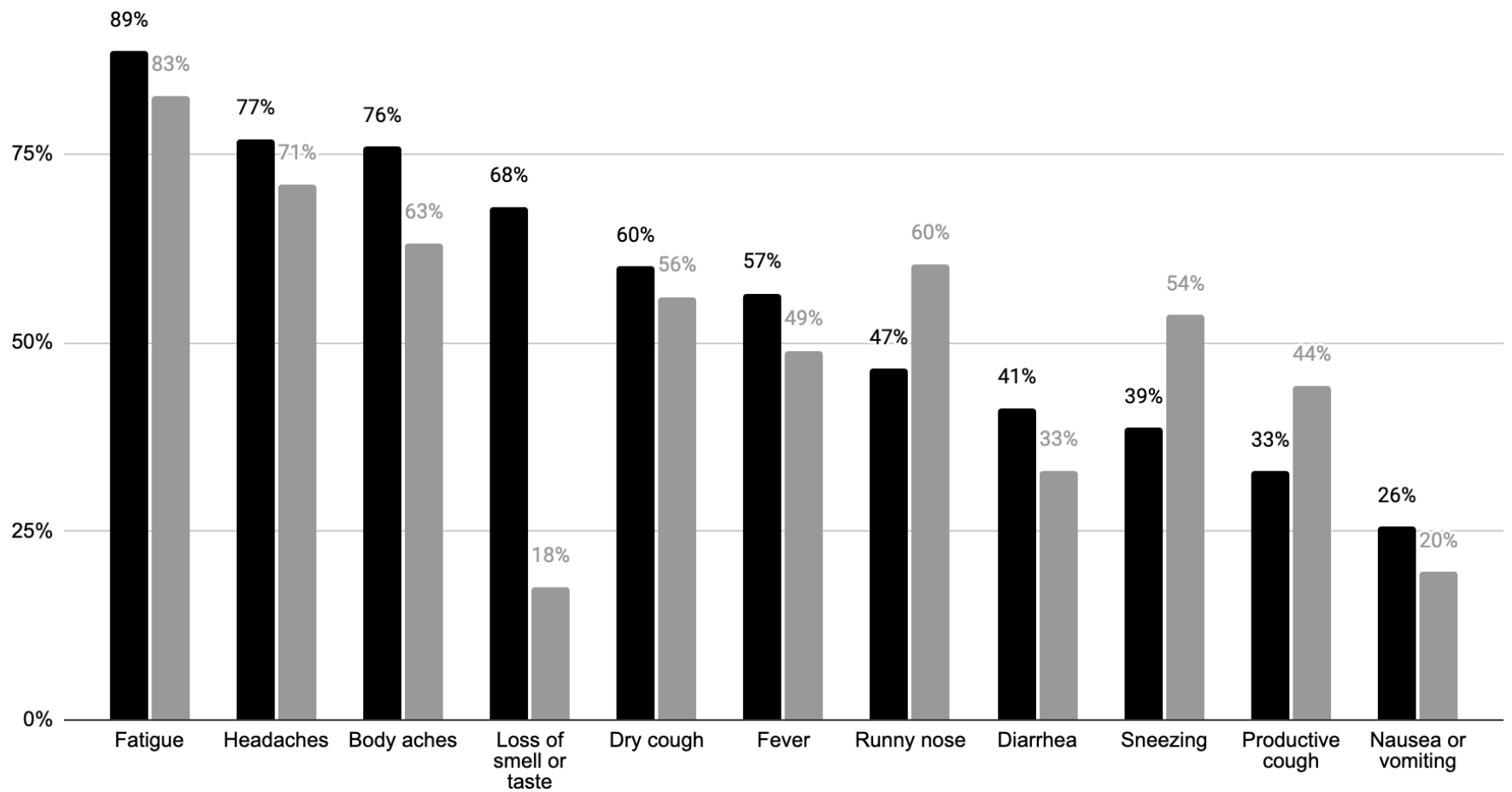


medRxiv preprint doi: https://doi.org/10.1101/2021.05.28.21257993; this version posted May 31, 2021. The copyright holder for this preprint (which was not certified by peer review) is the author/funder, who has granted medRxiv a license to display the preprint in perpetuity.

It is made available under a CC-BY-NC-ND 4.0 International license .

Supplementary Figure 2: Manhattan plot for the 'Loss of taste or smell' phenotype in the European population. SNPs achieving genome-wide significance are highlighted in red. The nearest gene to each index SNP is indicated above the relevant association peaks.

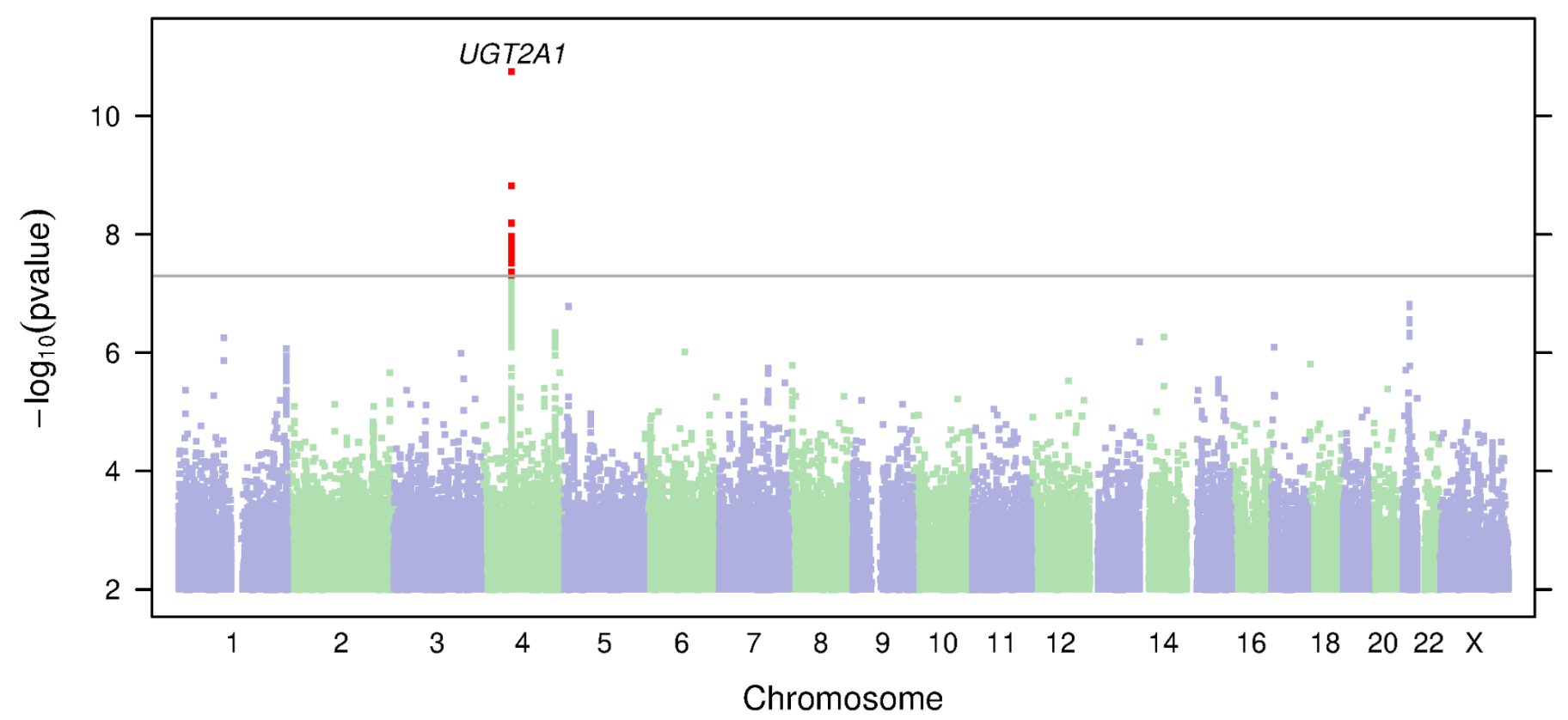

Supplementary Figure 3: Manhattan plot for the 'Loss of taste or smell' phenotype in the Latino population.

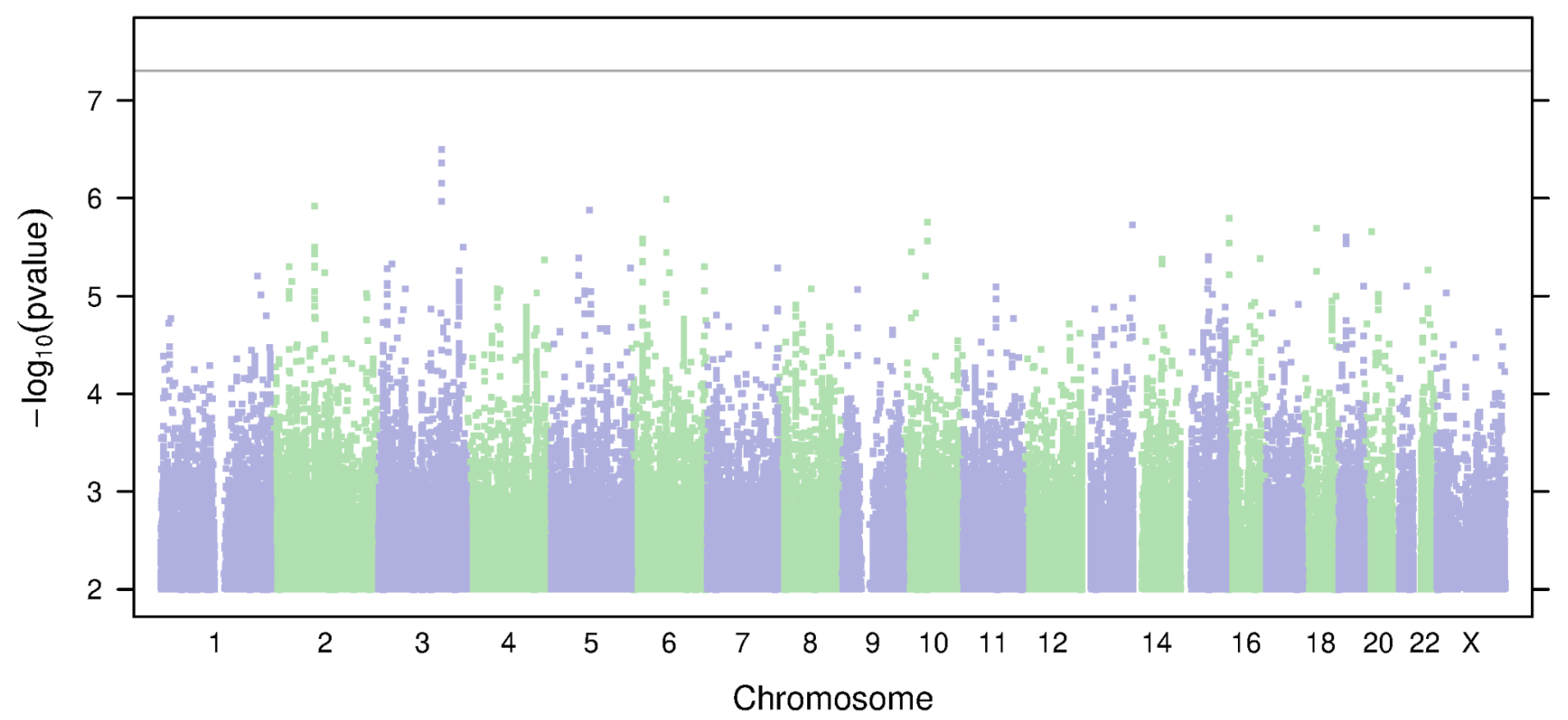


medRxiv preprint doi: https://doi.org/10.1101/2021.05.28.21257993; this version posted May 31, 2021. The copyright holder for this preprint (which was not certified by peer review) is the author/funder, who has granted medRxiv a license to display the preprint in perpetuity.

It is made available under a CC-BY-NC-ND 4.0 International license .

Supplementary Figure 4: Manhattan plot for the 'Loss of taste or smell' phenotype in the African American population.

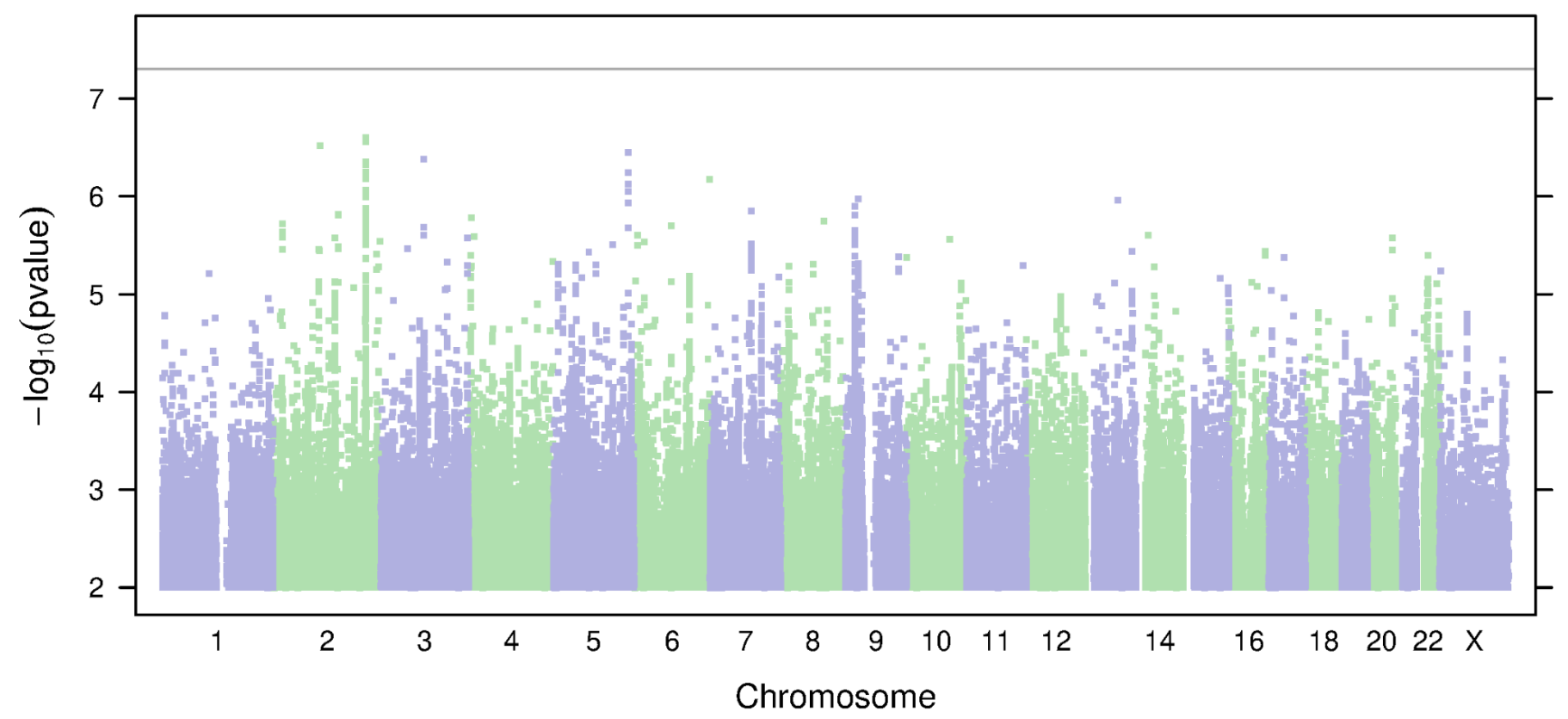

Supplementary Figure 5: Manhattan plot for the 'Loss of taste or smell' phenotype in the East Asian population.

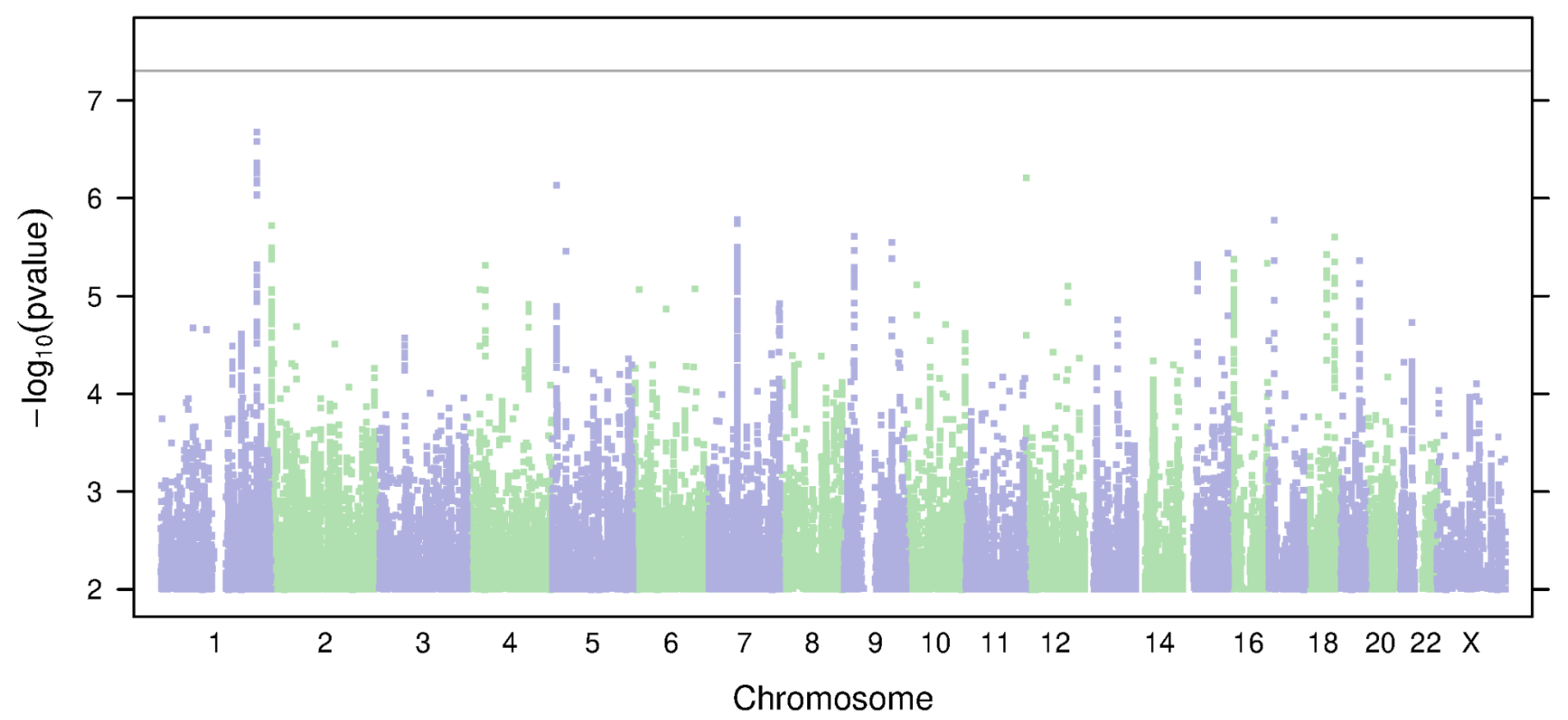


medRxiv preprint doi: https://doi.org/10.1101/2021.05.28.21257993; this version posted May 31, 2021. The copyright holder for this preprint (which was not certified by peer review) is the author/funder, who has granted medRxiv a license to display the preprint in perpetuity.

It is made available under a CC-BY-NC-ND 4.0 International license .

Supplementary Figure 6: Manhattan plot for the 'Loss of taste or smell' phenotype in the South Asian population.

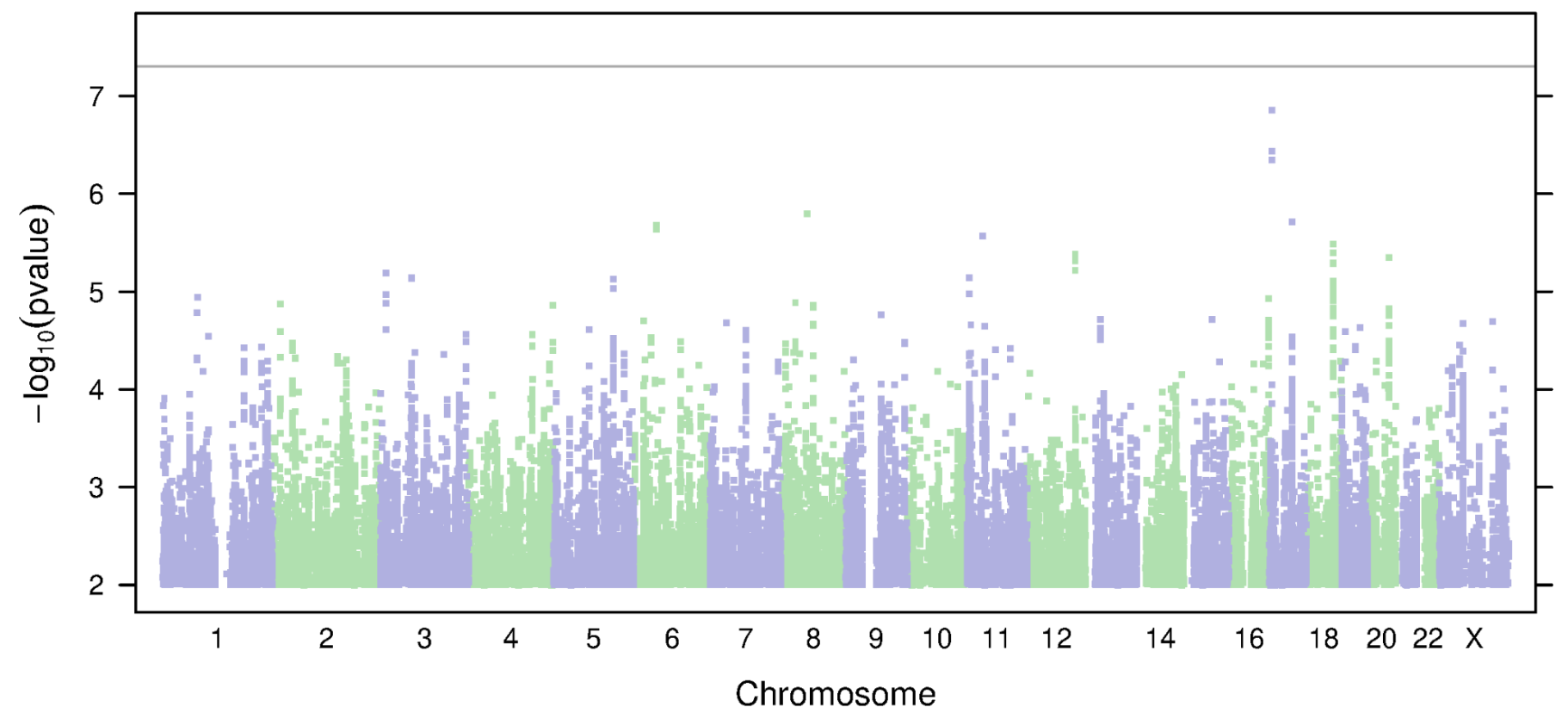


medRxiv preprint doi: https://doi.org/10.1101/2021.05.28.21257993; this version posted May 31, 2021. The copyright holder for this preprint (which was not certified by peer review) is the author/funder, who has granted medRxiv a license to display the preprint in perpetuity.

It is made available under a CC-BY-NC-ND 4.0 International license.

Supplementary Figure 7: Genetic associations with the 'Loss of taste or smell' phenotype. Regional plots around the UGT2A1 and UGT2A2 locus in the European population. Colors indicate strength of linkage disequilibrium relative to the index SNP (rs7688383). Imputed variants are indicated with ' + ' symbols or ' $x$ ' symbols for coding variants. Where imputed variants weren't available, directly genotyped variants are indicated by 'o' symbols or diamond symbols for coding variants.

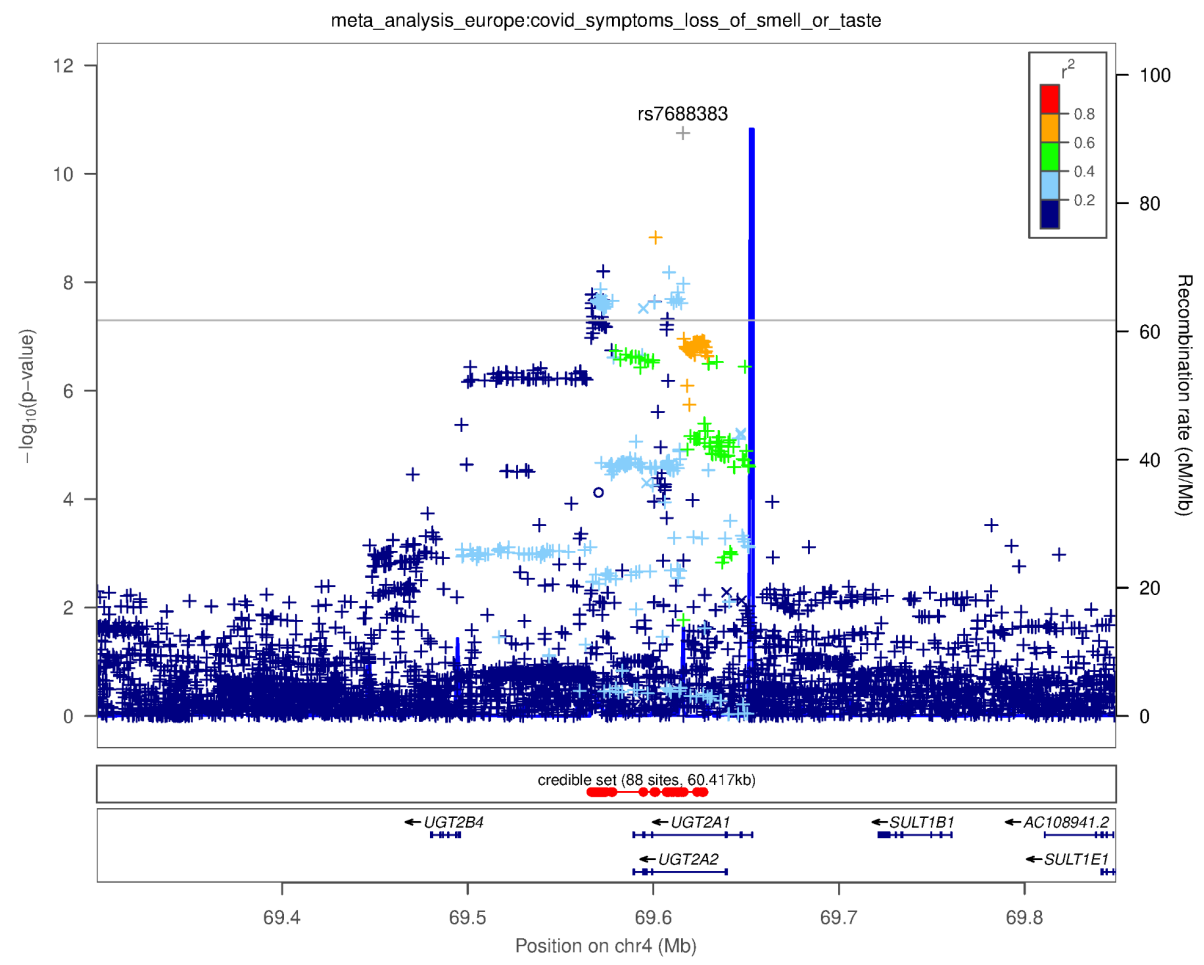

Supplementary Figure 8: Genetic associations with the 'Loss of taste or smell' phenotype. Regional plots around the UGT2A1/UGT2A2 locus in the Latino population. Colors indicate strength of linkage disequilibrium relative to the index SNP (rs7688383). Imputed variants are indicated with ' + ' symbols or ' $x$ ' symbols for coding variants. Where imputed variants weren't available, directly genotyped variants are indicated by 'o' symbols or diamond symbols for coding variants. 
medRxiv preprint doi: https://doi.org/10.1101/2021.05.28.21257993; this version posted May 31, 2021. The copyright holder for this preprint (which was not certified by peer review) is the author/funder, who has granted medRxiv a license to display the preprint in perpetuity.

It is made available under a CC-BY-NC-ND 4.0 International license .

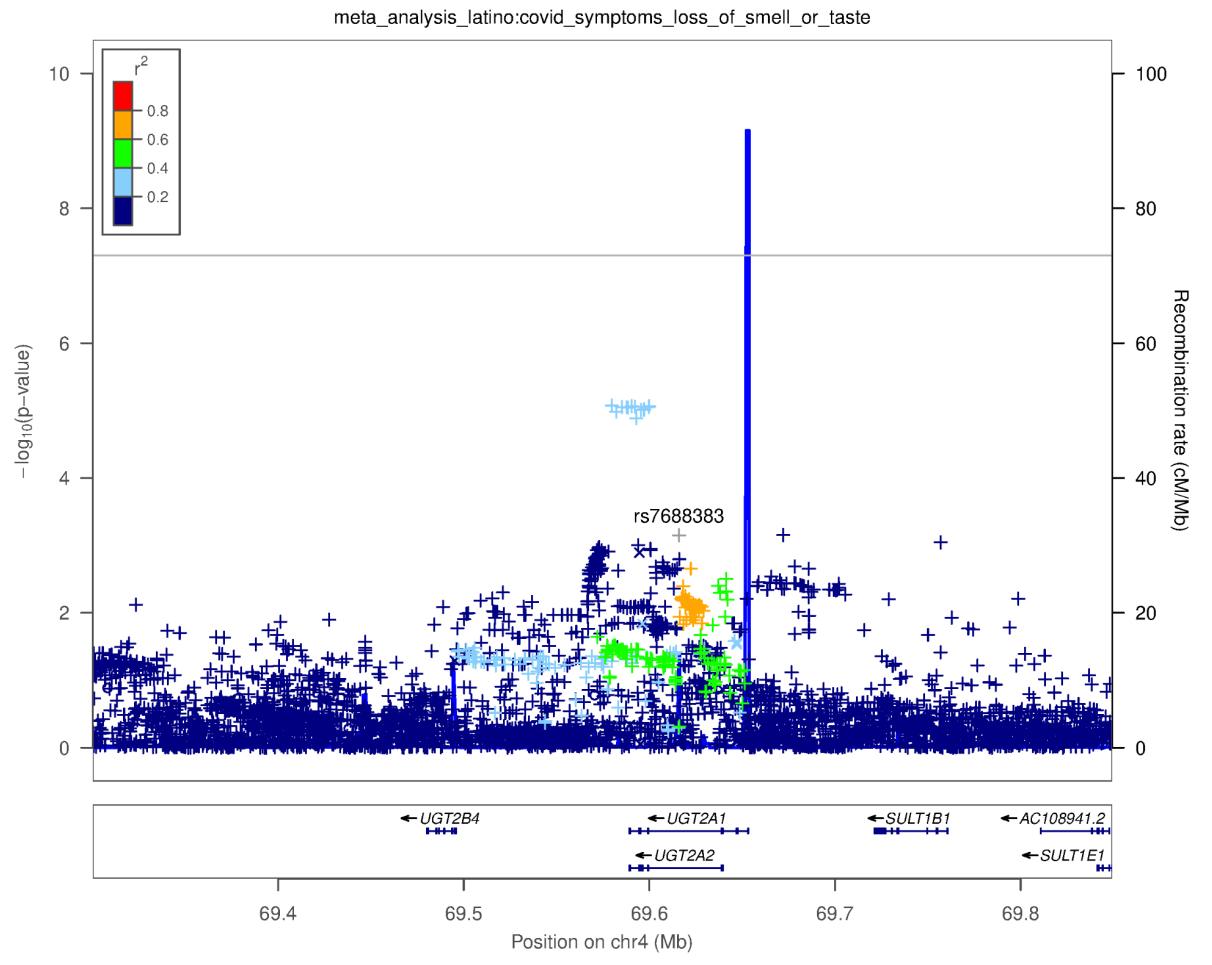

Supplementary Figure 9: Genetic associations with the 'Loss of taste or smell' phenotype. Regional plots around the UGT2A1/UGT2A2 locus in the African American population. Colors indicate strength of linkage disequilibrium relative to the index SNP (rs7688383). Imputed variants are indicated with '+' symbols or ' $\mathrm{x}$ ' symbols for coding variants. Where imputed variants weren't available, directly genotyped variants are indicated by 'o' symbols or diamond symbols for coding variants.

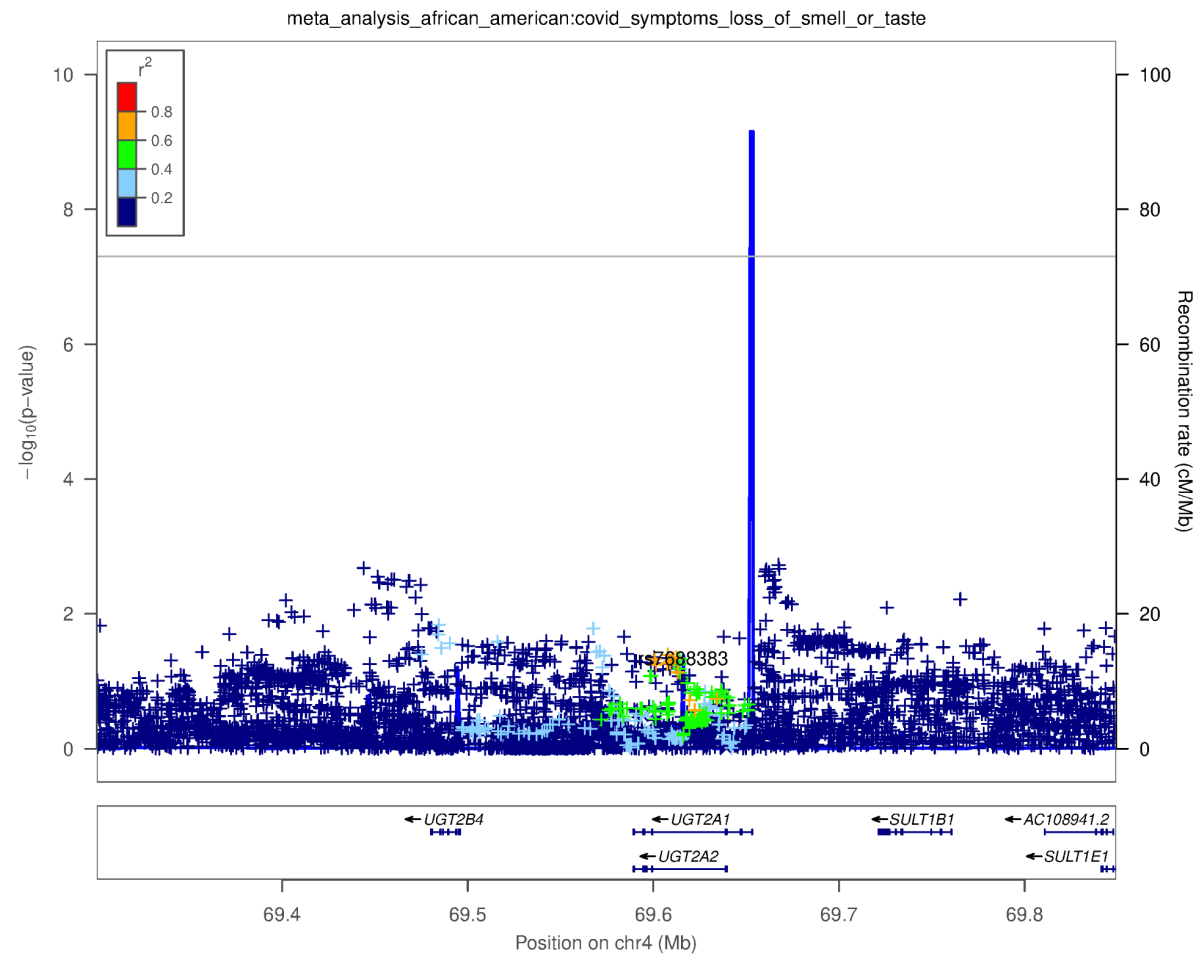

Supplementary Figure 10: Genetic associations with the 'Loss of taste or smell' phenotype. Regional plots around the UGT2A1/UGT2A2 locus in the East Asian population. Colors indicate strength of linkage disequilibrium relative to the index SNP (rs7688383). Imputed variants are indicated with '+' symbols or ' $x$ ' 
medRxiv preprint doi: https://doi.org/10.1101/2021.05.28.21257993; this version posted May 31, 2021. The copyright holder for this preprint (which was not certified by peer review) is the author/funder, who has granted medRxiv a license to display the preprint in perpetuity.

It is made available under a CC-BY-NC-ND 4.0 International license .

symbols for coding variants. Where imputed variants weren't available, directly genotyped variants are indicated by 'o' symbols or diamond symbols for coding variants.

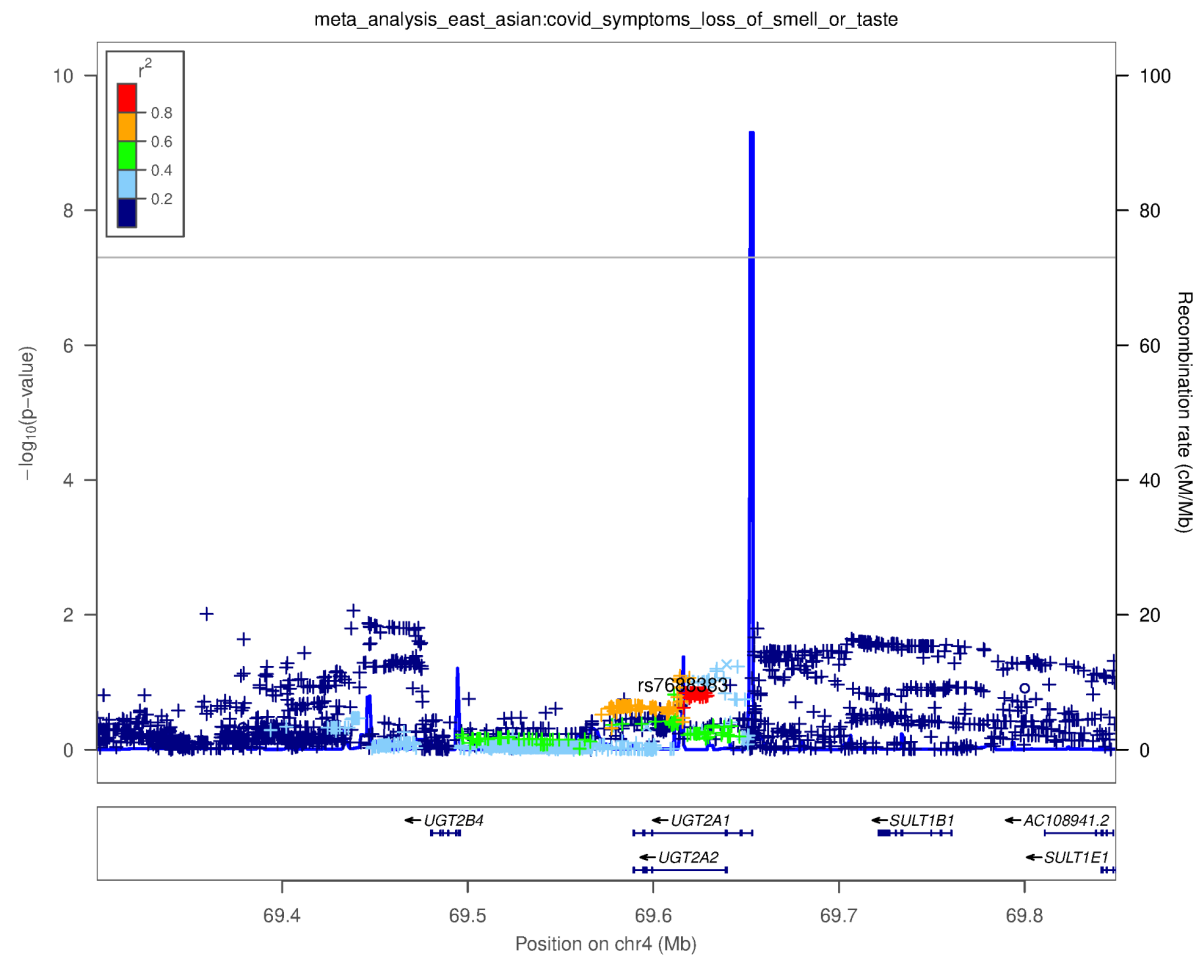

Supplementary Figure 11: Genetic associations with the 'Loss of taste or smell' phenotype. Regional plots around the UGT2A1/UGT2A2 locus in the South Asian population. Colors indicate strength of linkage disequilibrium relative to the index SNP (rs7688383). Imputed variants are indicated with '+' symbols or ' $x$ ' symbols for coding variants. Where imputed variants weren't available, directly genotyped variants are indicated by 'o' symbols or diamond symbols for coding variants.

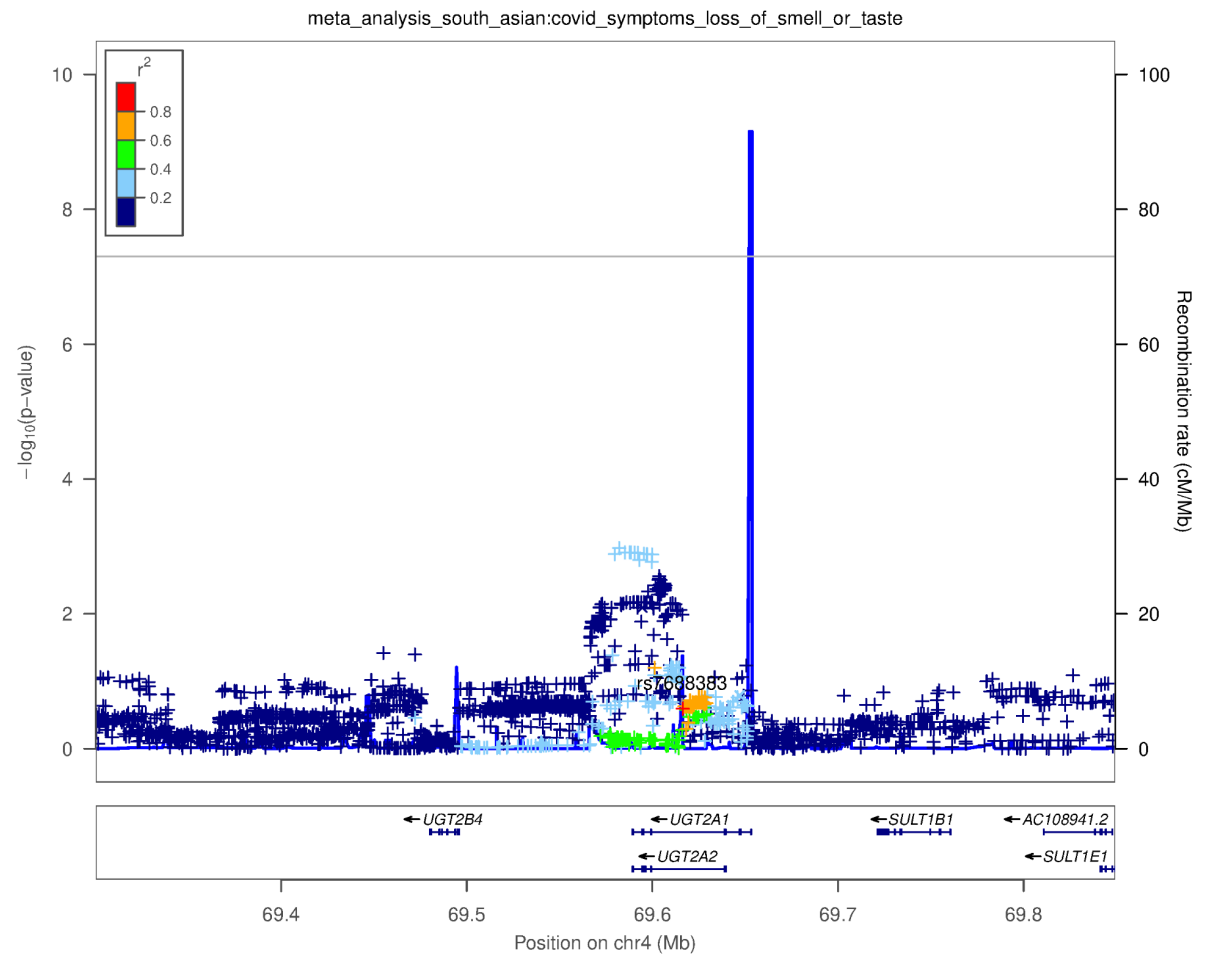


medRxiv preprint doi: https://doi.org/10.1101/2021.05.28.21257993; this version posted May 31, 2021. The copyright holder for this preprint (which was not certified by peer review) is the author/funder, who has granted medRxiv a license to display the preprint in perpetuity. It is made available under a CC-BY-NC-ND 4.0 International license .

Data availability

The full set of de-identified summary statistics can be made available to qualified investigators who enter into an agreement with 23 andMe that protects participant confidentiality. Interested investigators should visit the following: https://research.23andme.com/covid19-dataset-access/. 